\title{
Karakteristik Pasien Diabetes Melitus Non Ulkus Yang Mengikuti Program Pengelolaan Penyakit Kronis (Studi Awal)
}

\author{
Nuniek Nizmah Fajriyah ${ }^{1 *}$, Nurul Aktifa ${ }^{2}$, Firman Faradisi ${ }^{3}$ \\ ${ }^{1,3}$ Prodi D III Keperawatan, STIKES Muhammadiyah Pekajangan Pekalongan \\ ${ }^{2}$ Prodi S1 Fisioterapi, STIKES Muhammadiyah Pekajangan Pekalongan \\ *Email: nuniek@stikesmuh-pkj.ac.id
}

\section{Kata Kunci \\ Karakteristik pasien Diabetes non ulkus., program pengelolaan penyakit kronis.}

\begin{abstract}
Abstrak
Diabetes melitus dibandingkan dengan penderita non Diabetes melitus mempunyai kecenderungan $50 \mathrm{X}$ menderita ulkus diabetika. Penelitian ini bertujuan untuk mengetahui karakteristik pasien diabetes melitus non ulkus yang mengikuti program pengelolaan penyakit kronis (Pronalis).. Desain penelitian ini adalah deskriptif dengan menggunakan kuesioner sebagai instrumen. Sampel yang digunakan dengan insidental sampling. Analisa data menggunakan univariat. Hasil penelitian menunjukan bahwa sebagian besar responden memiliki kategori lansia awal (46-55 tahun) sebanyak 66 orang (46,2\%), sebagian besar responden adalah perempuan sebanyak 96 orang (67,1\%), sebagian besar responden berpendidikan SD (Sekolah Dasar) sebanyak 82 orang (57,3\%), sebagian besar responden bekerja sebanyak 76 orang $(53,1 \%)$, sebagian besar responden yang memiliki kategori diabet $(\geq 200$ $\mathrm{mg} / \mathrm{dl}$ ) sebanyak 82 orang $(57,3 \%)$, sebagian besar responden memiliki kategori normotensi sebanyak 107 orang $(74,8 \%)$, sebagian besar Responden yang memiliki kategori normal (IMT 18,5-22,9) sebanyak 51 orang $(35,7 \%)$, sebagian besar responden mengalami obesitas abdominal sebanyak 83 orang (58\%). Hasil penelitian ini sebagai masukan tenaga kesehatan dalam pengelolaan program penyakit kronis khususnya Diabetes Melitus.
\end{abstract}

\section{The Characteristics Of Non Ulkus Diabetes Melitus Patients Whose Follow The Program of Chronic Disease Management (Preliminary Study)}

\begin{abstract}
Diabetes mellitus compared with non Diabetes mellitus have tendency 50 times for suffer diabetic ulcers. This research aims to know the characteristics of patients with non-ulcer diabetes mellitus who follow the program of management of chronic diseases (Pronalis). The design of this research was descriptive by using questionnaire as an instrument. The sample used was incidental sampling. Data analysis using univariate. The result of the research showed that most respondents had the category of early age (46-55 years) as many as 66 people (46,2\%), most of them were women $(96,1 \%)$, most of them were elementary school) as many as 82 people (57.3\%), most respondents worked as many as 76 people (53.1\%), most respondents had diabet category ( $\geq 200 \mathrm{mg} / \mathrm{dl}$ ) as many as 82 people $(57.3 \%)$, the respondent had normotensi category, as many as 107 people (74,8\%), most of respondent had normal category (IMT 18,5-22,9) as many as 51 people (35,7\%), most of them had abdominal obesity 83 people (58\%). The results of this study as the input of health personnel in the management of chronic disease programs, especially Diabetes Mellitus.
\end{abstract}


PROFESI (Profesional Islam)

Media Publikasi Penelitian; 2017; Volume 15; No 1.

Website: ejournal.stikespku.ac.id

\section{PENDAHULUAN}

Penyakit tidak menular (PTM) sudah menjadi penyebab kematian yang lebih umum bila dibandingkan dengan penyakit akibat infeksi di negara sedang berkembang. Oleh karena itu, negara yang sedang berkembang dihadapkan pada dua beban kesehatan, yaitu beban terhadap infeksi yang besar dan juga meningkatnya beban penyakit tidak menular. Indonesia adalah salah satu negara sedang berkembang dimana proporsi kematian akibat penyakit menular dalam 12 tahun terakhir mengalami penurunan dari $44 \%$ menjadi $28 \%$ dan proporsi kematian akibat PTM mengalami peningkatan dari $42 \%$ menjadi $60 \%$ (Butarbutar, Hiswani, \& Jemadi, 2012).

Salah satu penyakit tidak menular yang menjadi masalah pada berbagai negara yaitu Diabetes melitus (DM). Diabetes melitusatau penyakit kencing manis merupakan penyakit kronis akibat adanya gangguan metabolik yang ditandai dengan meningkatnya kadar glukosa dalam darah (hiperglikemi). Hal ini dapat terjadi akibat defisiensi sekresi insulin, berkurangnya efektifitas biologis dari insulin maupun keduanya (Rendy \& Margareth, 2012, h.164).

Diabetes Melitus (DM) telah menjadi masalah kesehatan utama di dunia dengan angkakejadian dan kematian yang masih sangat tinggi. Menurut World Health Organization (WHO) (2017) menyatakan bahwa angka kejadian diabetes melitus sebanyak 108 juta pada tahun 1980 menjadi 422 juta pada tahun 2014. Pada tahun 2015 diabetes melitus merupakan penyakit mematikan ke-6 di dunia dengan angka 1,6 juta orang tiap tahunnya dalam 15 tahun terakhir. Berdasarkan data yang diperoleh Riset Kesehatan Dasar (Riskesdas) (2013) menyatakan bahwa prevalensi diabetes melitus di Indonesia berdasarkan diagnosis atau gejala sebanyak 2,1\% dari keseluruhan penduduk.

Diabetes melitus dibandingkan dengan penderita non Diabetes melitus mempunyai kecenderungan $2 \mathrm{X}$ lebih mudah mengalami trombosis serebral, $25 \mathrm{X}$ terjadi buta, $2 \mathrm{X}$ terjadi penyakit jantung koroner, $17 \mathrm{X}$ terjadi gagal ginjal kronik, dan $50 \mathrm{X}$ menderita ulkus diabetika. Komplikasi menahun Diabetes melitus di Indonesia terdiri atas neuropati $60 \%$, penyakit jantung koroner
20,5\%, ulkus diabetika $15 \%$, retinopati $10 \%$, dan nefropati 7,1\% (Waspaji. S, 2007).

Prevalensi diabetes melitus di Jawa Tengah pada tahun 2015 menempati urutan ke-2 setelah penyakit hipertensi dengan persentase 18,33\% atau sebanyak 110.702 orang, diabetes melitus tipe 1 sebanyak 8.611 orang dan diabetes melitus tipe 2 sebanyak 102.091 orang. Prevalensi diabetes melitus tertinggi berada di Kabupaten Demak sebanyak 15.064 orang, Kabupaten Klaten sebanyak 7.482, dan disusul Kabupaten Pati sebanyak 5.220 orang (Dinkes Jateng, 2015). Sedangkan angka kejadian diabetes melitus di Wilayah Kabupaten Pekalongan pada tahun 2015 hingga tahun 2016 mengalami peningkatan. Berdasarkan data Dinas Kesehatan Kabupaten Pekalongan tahun 2016 ada sebanyak 1.490 orang dengan diabetes melitus. Hal tersebut jauh lebih tinggi dibandingkan pada tahun 2015 yang hanya mencapai 1.408 orang dengan diabetes melitus. Prevalensi paling banyak di Puskesmas Kajen II sebanyak 211 orang, kemudian Puskesmas Karangdadap sebanyak 130 orang dan di Puskesmas Tirto I sebanyak 129 orang. (Dinkes Kab. Pekalongan, 2016).

Di Indonesia sudah ada suatu Program Pengelolaan Penyakit Kronis (Pronalis) yang merupakan suatu upaya promotif dan preventif dalam pengelolaan penyakit kronis termasuk diabetes melitus dan hipertensi pada pasien yang merupakan peserta Badan Penyelenggara Jaminan Sosial (BPJS) Kesehatan untuk mencegah komplikasi, peningkatan kualitas hidup, dan pembiayaan jaminan kesehatan yang efektif dan efisien (BPJS, 2014). Di prolanis ini juga disediakan dokter keluarga yang bertugas sebagai gate keeper yang tidak hanya memilih pasien untuk dirujuk ke spesialis terkait, tetapi juga dapat memberikan pelayanan komprehensif dan terfokus dalam upaya promotif dan preventif (Hidayat, 2010).

Alasan tersebut di atas menjadikan peneliti tertarik melakukan penelitian tentang "Karakteristik Pasien Diabetes Melitus Non Ulkus yang Mengikuti Program Pengelolaan Penyakit Kronis (Pronalis) di Wilayah Puskesmas Kabupaten Pekalongan".

Berdasarkan uraian latar belakang tersebut maka dapat memunculkan masalah yaitu "Bagai- 
mana Karakteristik Pasien Diabetes Melitus Non Ulkus yang Mengikuti Program Pengelolaan Penyakit Kronis (Pronalis) di Wilayah Puskesmas Kabupaten Pekalongan?".

Penelitian ini bertujuan untuk mengetahui karakteristik pasien diabetes melitus non ulkus yang mengikuti program pengelolaan penyakit kronis (Pronalis) di Wilayah Puskesmas Kabupaten Pekalongan.

\section{METODE PENELITIAN}

Penelitian ini menggunakan desain penelitian deskriptif dengan menggunakan kuesioner sebagai instrumen dan dilaksanakan di Puskesmas Kabupaten Pekalongan yang memiliki peserta Prolanis (Program Pengelolaan Penyakit Kronis) terbanyak di Puskesmas Kabupaten Pekalongan yang diambil dari 4 Puskesmas di Kabupaten Pekalongan. Penelitian dilaksanakan dari Maret sampai Agustus 2017.

Sampel yang digunakan adalah menggunakan metode convenient sampling, yaitu pemilihan sampel dengan pertimbangan kemudahan peneliti dalam memilih sampel (accidental sampling). Jumlah sampel 143 responden, dengan menggunakan analisis univariat.

\section{HASIL DAN PEMBAHASAN}

\subsection{Usia}

Berdasarkan data penelitian diperoleh informasi tentang karakteristik usia pasien diabetes melitus non ulkus di Wilayah Puskesmas Kabupaten Pekalongan, dapat dilihat dalam tabel dibawah ini:

Tabel 1. Distribusi Frekuensi Responden Berdasarkan Usia Pasien

\begin{tabular}{lcc}
\hline \multicolumn{1}{c}{ Usia } & Frekuensi & $\%$ \\
\hline Dewasa Awal & 1 & 0,7 \\
Dewasa Akhir & 15 & 10,5 \\
Lansia Awal & 66 & 46,2 \\
Lansia Akhir & 51 & 35,7 \\
Manula & 10 & 7 \\
\hline Total & 143 & 100 \\
\hline
\end{tabular}

Berdasarkan hasil dari penelitian, diperoleh data sebagian besar responden memiliki kategori lansia awal (46-55 tahun) sebanyak 66 orang $(46,2 \%)$. Responden yang memiliki kategori lansia akhir (56-65 tahun) sebanyak 51 orang
$(35,7 \%)$. Responden yang memiliki kategori dewasa akhir (36-45 tahun) sebanyak 15 orang $(10,5 \%)$. Responden yang memiliki kategori manula (>65 tahun) sebanyak 10 orang (7\%). Sedangkan responden yang memiliki kategori usia dewasa awal (26-35 tahun) sebanyak 1 orang $(0,7 \%)$.

Harfika (2010) mengatakan bahwa resiko untuk menderita intoleransi glukosa meningkat seiring dengan meningkatnya usia. Berdasarkan penelitian Jelantik \& Haryati (2013) tentang "Hubungan Faktor Risiko Umur, Jenis Kelamin, Kegemukan dan Hipertensi dengan Kejadian Diabetes Mellitus tipe II di Wilayah Kerja Puskesmas Mataram" mengatakan bahwa ada hubungan yang bermakna antara umur dengan kejadian diabetes melitus tipe II.

Hal ini juga sesuai dengan teori yang dikemukakan oleh Smeltzer \& Bare (2002) (dikutip dalam Ngurah \& Sukmayanti, 2014) mengatakan bahwa biasanya diabetes melitus banyak dialami oleh usia 40-60 tahun karena resistensi insulin. Usia sangat erat kaitannya dengan kenaikan kadar gula dalam darah, proses menua mengakibatkan perubahan anatomis, fisiologis dan biokimia.

\subsection{Jenis Kelamin}

Berdasarkan data penelitian diperoleh informasi tentang jenis kelamin pasien diabetes mellitus non ulkus di Wilayah Puskesmas Kabupaten Pekalongan, dapat dilihat dalam tabel dibawah ini:

Tabel 2. Distribusi Frekuensi Responden Berdasarkan Jenis Kelamin

\begin{tabular}{lcc}
\hline \multicolumn{1}{c}{ Jenis Kelamin } & Frekuensi & $\%$ \\
\hline Laki-Laki & 47 & 32,9 \\
Perempuan & 96 & 67,1 \\
\hline Total & 143 & 100 \\
\hline
\end{tabular}

Berdasarkan hasil dari penelitian, diperoleh data sebagian besar responden adalah perempuan sebanyak 96 orang $(67,1 \%)$. Sedangkan responden laki-laki sebanyak sebanyak 47 orang $(32,9 \%)$.

Radi (2007 dalam Ariani, 2011) (dikutip dalam Ngurah \& Sukmayanti, 2014) mengatakan bahwa tingginya kejadian DM tipe II pada perempuan dipengaruhi oleh beberapa faktor 
risiko, seperti obesitas, kurang aktivitas/latihan fisik, usia, dan riwayat DM saat hamil. Hal ini sesuai dengan hasil penelitian Ariani (2011) mengenai "Hubungan Motivasi dengan Efikasi Diri pada Pasien Diabetes Melitus tipe II" sebagian besar responden $(60 \%)$ berjenis kelamin perempuan.

\subsection{Pendidikan}

Berdasarkan data penelitian diperoleh informasi tentang karakteristik pendidikan pasien diabetes melitus non ulkus di Wilayah Puskesmas Kabupaten Pekalongan, dapat dilihat dalam tabel dibawah ini:

Tabel 3. Distribusi Frekuensi Responden Berdasarkan Pendidikan

\begin{tabular}{lcc}
\hline \multicolumn{1}{c}{ Pendidikan } & Frekuensi & $\%$ \\
\hline Tidak Sekolah & 26 & 18,2 \\
SD & 82 & 57,3 \\
SMP & 16 & 11,2 \\
SMA & 12 & 8,4 \\
D3 & 1 & 0,7 \\
Sarjana & 6 & 4,2 \\
\hline Total & 143 & 100 \\
\hline
\end{tabular}

Berdasarkan hasil dari penelitian, diperoleh data sebagian besar responden berpendidikan SD (Sekolah Dasar) sebanyak 82 orang $(57,3 \%)$. Responden yang tidak sekolah sebanyak 26orang (18,2\%). Responden yang berpendidikan SMP (Sekolah Menengah Pertama) sebanyak 16 orang $(11,2 \%)$. Responden yang berpendidikan SMA (Sekolah Menengah Pertama) sebanyak 12 orang $(8,4 \%)$. Responden yang berpendidikan sarjana sebanyak 6 orang $(4,2 \%)$. Sedangkan responden yang berpendidikan D3 (Diploma) sebanyak 1 orang $(0,7 \%)$.

Notoatmodjo (2003 dalam Mubarak, 2006, h.137) (dikutip dalam Ratnasari, Kristiyawati, \& Solechan, 2013) mengatakan bahwa pendidikan pada hakekatnya merupakan usaha untuk membantu individu dalam meningkatkan kemampuan atau perilaku untuk mencapai kesehatan optimal.

Bariroh, Setyawan, \& Sakudarno (2016) mengatakan bahwa tingkat pendidikan seseorang dapat mendukung atau mempengaruhi tingkat pengetahuan seseorang.
Pendidikan yang rendah maka pengetahuan juga rendah, semakin tinggi pendidikan seseorang maka pengetahuannya akan semakin tinggi. Pasien yang memiliki pendidikan yang lebih tinggi akan mempunyai pengetahuan yang lebih luas juga memungkinkan pasien dapat mengontrol dirinya dalam mengatasi masalah yang dihadapi, mempunyai rasa percaya diri yang tinggi, berpengalaman dan mempunyai perkiraan yang tepat bagaimana mengatasi kejadian serta mudah mengerti anjuran-anjuran dari petugas kesehatan.

\subsection{Pekerjaan}

Berdasarkan data penelitian diperoleh informasi tentang karakteristik pekerjaan pasien diabetes mellitus non ulkus di Wilayah Puskesmas Kabupaten Pekalongan, dapat dilihat dalam tabel dibawah ini:

Tabel 4. Distribusi Frekuensi Responden Berdasarkan Pekerjaan

\begin{tabular}{lcc}
\hline \multicolumn{1}{c}{ Pekerjaan } & Frekuensi & $\%$ \\
\hline Bekerja & 76 & 53,1 \\
Tidak Bekerja & 67 & 46,9 \\
\hline Total & 115 & 100 \\
\hline
\end{tabular}

Berdasarkan hasil dari penelitian, diperoleh data sebagian besar responden yang bekerja sebanyak 76 orang $(53,1 \%)$. Sedangkan responden yang tidak bekerja sebanyak 67 orang $(46,9 \%)$.

Vitahealth (2005) (dikutip dalam Ngurah \& Sukmayanti, 2014) mengatakan bahwa salah satu faktor penyebab terjadinya DM adalah stres. Tingkat gula darah tergantung pada kegiatan hormon yang dikeluarkan oleh kelenjar adrenal, yaitu adrenalin dan kortikosteroid. Kondisi pekerjaan merupakan salah satu stressor bagi penderita DM, yang dapat menurunkan kemampuan seseorang untuk menyelesaikan masalah.

Ngurah \& Sukmayanti (2014) mengatakan bahwa seseorang yang tidak bekerja dengan yang bekerja tentu akan memiliki tingkat stres yang berbeda. Terlebih lagi tuntutan ekonomi yang semakin meningkat setiap harinya akan menuntut seseorang untuk memenuhi kebutuhan hidupnya. 


\subsection{Gula Darah Sewaktu}

Berdasarkan data penelitian diperoleh informasi tentang karakteristik gula darah sewaktu pasien diabetes mellitus non ulkus di Puskesmas Kabupaten Pekalongan, dapat dilihat dalam tabel dibawah ini:

Tabel 5. Distribusi Frekuensi Responden Bedasarkan Gula Darah Sewaktu

\begin{tabular}{lcc}
\hline \multicolumn{1}{c}{ GDS } & Frekuensi & $\%$ \\
\hline Pra-diabet & 61 & 42,7 \\
Diabet & 82 & 57,3 \\
\hline Total & 143 & 100 \\
\hline
\end{tabular}

Berdasarkan hasil dari penelitian, diperoleh data sebagian besar responden yang memiliki kategori diabet $(\geq 200 \mathrm{mg} / \mathrm{dl})$ sebanyak 82 orang $(57,3 \%)$. Sedangkan responden yang memiliki kategori pra-diabet $(90-199 \mathrm{mg} / \mathrm{dl})$ sebanyak 61 orang $(42,7 \%)$.

Glukosa merupakan karbohidrat terpenting yang kebanyakan diserap oleh aliran darah sebagai glukosa dan gula lain diubah menjadi glukosa di hati. Glukosa adalah bahan bakar utama dalam jaringan tubuh serta berfungsi untuk menghasilkan energi. Kadar glukosa darah sangat erat kaitannya dengan penyakit diabetes mellitus. Peningkatan kadar glukosa darah sewaktu $\geq 200$ $\mathrm{mg} / \mathrm{dL}$ yang disertai dengan gejala poliuria, polidipsia, polifagia, dan penurunan berat badan yang tidak dapat dijelaskan sebabnya sudah cukup untuk menegakkan diagnosis diabetes mellitus (Amir, Wungouw \& Pangemanan, 2015).

\subsection{Tekanan Darah}

Berdasarkan data penelitian diperoleh informasi tentang karakteristik tekanan darah pasien diabetes melitus non ulkus di Puskesmas Kabupaten Pekalongan, dapat dilihat dalam tabel dibawah ini:

Tabel 6. Distribusi Frekuensi Responden Berdasarkan Tekanan Darah

\begin{tabular}{lcc}
\hline \multicolumn{1}{c}{ Tekanan Darah } & Frekuensi & $\%$ \\
\hline Normotensi & 107 & 74,8 \\
Hipertensi & 36 & 25,2 \\
\hline Normal & 143 & 100 \\
\hline
\end{tabular}

Berdasarkan hasil dari penelitian, diperoleh data sebagian besar responden memiliki kategori normotensi sebanyak 107 orang $(74,8 \%)$. Sedangkan responden yang memiliki kategori hipertensi sebanyak 36 orang $(25,2 \%)$.

Tekanan darah adalah tekanan dari darah yang dipompa oleh jantung terhadap dinding arteri. Pada manusia, darah dipompa melalui dua sistem sirkulasi terpisah dalam jantung yaitu sirkulasi pulmonal dan sirkulasi sistemik. Tekanan darah penting karena merupakan kekuatan pendorong bagi darah agar dapat beredar ke seluruh tubuh untuk memberikan darah segar yang mengandung oksigen dan nutrisi ke organ-organ tubuh (Amiruddin, Danes \& Lintong, 2015).

\subsection{Indeks Masa Tubuh}

Berdasarkan data penelitian diperoleh informasi tentang Indeks Massa Tubuh (IMT) pasien diabetes mellitus non ulkus di Puskesmas Kabupaten Pekalongan, dapat dilihat dalam tabel dibawah ini:

Tabel 7. Distribusi Frekuensi Responden Bedasarkan Indeks Massa Tubuh

\begin{tabular}{lcc}
\hline \multicolumn{1}{c}{ IMT } & Frekuensi & $\%$ \\
\hline Berat Badan & 14 & 9,8 \\
Kurang & & \\
Normal & 51 & 35,7 \\
Beresiko & 36 & 25,2 \\
Obesitas I & 35 & 24,5 \\
Obesitas II & 7 & 4,9 \\
\hline Total & 143 & 100 \\
\hline
\end{tabular}

Berdasarkan hasil dari penelitian, diperoleh data sebagian besar Responden yang memiliki kategori normal (IMT 18,5-22,9) sebanyak 51 orang $(35,7 \%)$. Responden yang memiliki kategori berisiko (IMT 23-24,9) sebanyak 36 orang $(25,2 \%)$. Responden yang memiliki kategori obesitas I (IMT 23-24,9) sebanyak 35 orang $(24,5 \%)$. Responden yang memiliki kategori berat badan kurang (IMT <18,5) sebanyak 14 orang $(9,8 \%)$. Sedangkan responden yang memiliki kategori obesitas II (IMT >30) sebanyak 7 orang $(4,9 \%)$.

Antropometri merupakan salah satu cara penentuan status gizi. Penentuan status gizi yang digunakan adalah pembagian berat badan dalam kilo gram $(\mathrm{Kg})$ dengan tinggi badan dalam meter kuadrat dinyatakan dalam indeks masa tubuh atau 
IMT. IMT memiliki kaitan dengan kadar gula darah penderita DM (Hartono, 2006 dalam Adnan, Mulyati \&Isworo, 2013). Indeks masa tubuh menggambarkan distribusi lemak tubuh yang sifatnya menyeluruh (Wiardani \& Kusumayanti, 2010).

\subsection{Lingkar Perut}

Berdasarkan data penelitian diperoleh informasi tentang lingkar perut pasien diabetes mellitus non ulkus di Puskesmas Kabupaten Pekalongan, dapat dilihat dalam tabel dibawah ini:

Tabel 8. Distribusi Frekuensi Responden Berdasarkan Lingkar Perut

\begin{tabular}{lcc}
\hline \multicolumn{1}{c}{ Lingkar Perut } & Frekuensi & $\%$ \\
\hline Normal & 60 & 42 \\
Obesitas & 83 & 58 \\
Abdominal & & \\
\hline Total & 143 & 100 \\
\hline
\end{tabular}

Berdasarkan hasil dari penelitian, diperoleh data sebagian besar responden mengalami obesitas abdominal sebanyak 83 orang (58\%). Sedangkan responden yang memiliki lingkar perut normal sebanyak 60 orang $(42 \%)$.

Lingkar perut menggambarkan ada tidaknya penumpukan lemak di daerah visceral/sentral yang sering disebut obesitas sentral (Wiardani \& Kusumayanti, 2010).

\section{SIMPULAN}

1. Sebagian besar responden memiliki kategori lansia awal (46-55 tahun) sebanyak 66 orang $(46,2 \%)$.

2. Sebagian besar responden adalah perempuan sebanyak 96 orang $(67,1 \%)$.

3. Sebagian besar responden berpendidikan SD (Sekolah Dasar) sebanyak 82 orang $(57,3 \%)$

4. Sebagian besar responden bekerja sebanyak 76 orang $(53,1 \%)$

5. Sebagian besar responden yang memiliki kategori diabet $(\geq 200 \mathrm{mg} / \mathrm{dl})$ sebanyak 82 orang $(57,3 \%)$

6. Sebagian besar responden memiliki kategori normotensi sebanyak 107 orang $(74,8 \%)$.

7. Sebagian besar Responden yang memiliki kategori normal (IMT 18,5-22,9) sebanyak 51 orang $(35,7 \%)$
8. Sebagian besar responden mengalami obesitas abdominal sebanyak 83 orang $(58 \%)$.

\section{SARAN}

Hasil penelitian ini sebagai masukan tenaga kesehatan dalam pengelolaan program penyakit kronis khususnya Diabetes Melitus.

\section{REFERENSI}

Adnan, M., Mulyati, T., \& Isworo, J.T (2013). 'Hubungan Indeks Masa Tubuh (IMT) dengan Kadar Gula Darah Penderita Diabetes mellitus (DM) Tipe 2 Rawat Jalan di RS Tugurejo Semarang'. Jurnal Gizi Universitas Muhammadiyah Semarang. vol.2, no.1. hh. 18-24.

Amiruddin, M.A., Danes, V.R., \& Lintong, F. (2015). 'Analisa Hasil Pengukuran Tekanan Darah Antara Posisi Duduk dan Posisi Berdiri pada Mahasiswa Semester VII (Tujuh) TA.2014/2015 Fakultas Kedokteran Universitas Sam Ratulangi'. Jurnal eBiomedik (eBm). vol.3, no.1,hh.125-129.

Amir, S.M.J., Wungouw, H., \& Pangemanan, D. (2015). 'Kadar Glukosa Darah Sewaktu pada Pasien Diabetes Melitus Tipe 2 di Puskesmas Bahu Kota Manado'. Jurnal eBiomedik (eBm). vol.3, no.1,hh.32-40.

Bariroh, U., Setyawan, H., Sakundarno, N. (2016). 'Kualitas Hidup Berdasarkan Karakteristik Pasien Pasca Stroke Studi di RSUD Tugurejo Kota Semarang'. Jurnal Kesehatan Masyarakat. vol. 4, no.4.

Butarbutar, F., Hiswani, \& Jemadi. (2012). 'Karakteristik Penderita Diabetes Mellitus dengan Komplikasi yang di Rawat Inapdi RSUD Deli Serdang'. Jurnal Skripsi Mahasiswa Departemen Epidemiologi FKM USU. Medan.

Dinas Kesehatan Kabupaten Pekalongan. (2016). 'Laporan Penyakit Tidak Menular, data DINKES Kabupaten Pekalongan'.

Dinas Kesehatan Provinsi Jawa Tengah. (2015). 'Kasus Baru Penyakit Tidak Menular di 
Puskesmas dan Rumah Sakit Provinsi Jawa Tengah'.

Harfika, M. (2010). 'Karakteristik Penderita Diabetes Melitus Tipe 2di Instalasi Rawat Inap Penyakit Dalam Rumah Sakit Mohammad Hoesin Palembang'. no.73-79.

Irianto, K. (2015). Memahami Berbagai Macam Penyakit. Bandung: Alfabeta.

Jelantik, I.G.M.G.,\& Haryati, E. (2014). 'Hubungan Faktor Risiko Umur, Jenis Kelamin, Kegemukan Dan Hipertensi Dengan Kejadian Diabetes Mellitus Tipe Ii Di Wilayah KerjaPuskesmas Mataram'. Jurnal Media Bina Ilmiah. vol.8, no.1.

Munasipah. (2016). 'Gambaran Perilaku Pencegahan Luka Kaki PasienDiabetes Melitus di Desa Rowokembu Kecamatan Wonopringgo Kabupaten Pekalongan'. Jurnal Skripsi Mahasiswa Program Studi Ners Stikes Muhammadiyah Pekajangan Pekalongan.

Ngurah, I.G.K.G.,\& Sukmayanti, M. (2014). 'Efikasi Diri pada pasien Diabetes Mellitus Tipe II'. Jurnal Keperawatan Politekhnik Kesehatan Denpasar.
Ratnasari, P., Kristiyawati. S.P., Solechan, A. (2013) 'Hubungan Tingkat Ketergantungan Activity of daily Living dengan Depresi pada Pasien Stroke di RSUD Tugurejo Semarang'.

Rendy, M., C., Margareth, Th. (2012). Asuhan Keperawatan Medikal Bedah dan Penyakit Dalam. Yogyakarta: Nuha Medika.

Riset Kesehatan Dasar. (2013). Badan Penelitian dan Pengembangan Kesehatan. Kementrian Kesehatan RI. Jakarta.

Wiardani, N.K., \& Kusumayanti, G.A.D. (2010). 'Indeks Masa Tubuh, Lingkar Pinggang serta Tekanan Darah Penderita Diabetes Mellitus'.Jurnal Ilmu Gizi. vol.1, no.1, hh.18-27.

Waspadji S. Komplikasi kronik Diabetes: Mekanisme Terjadinya, Diagnosis dan Strategi pengelolaan. Dalam: Aru W, dkk, editors, Ilmu Penyakit Dalam, Jilid III, Edisi keempat, Penerbit FK UI, Jakarta, 2006.

World Health Organization. (2017). 'The Top 10 Causes of Death', diakses pada tanggal 2 Februari 2017 di http://www.who.int/ mediacentre/factsheets/fs310/en/\#.WMA7G_ WO_Dc.facebook. 